\title{
Metaproteomic Comparison of Cryoconite Communities from Caucasian and Novaya Zemlya Glaciers
}

\section{Bozhana Zainullina}

St. Petersburg State University Research Park

Irina Babkina

Institute of Cytology of the Russian Academy of Sciences

Arseniy Lobov ( $\square$ arseniylobov@gmail.com )

Institute of Cytology of the Russian Academy of Science https://orcid.org/0000-0002-0930-1171

\section{Rustam Tembotov}

Tembotov Institute of Mountain Regions

\section{Evgeniy Abakumov}

St. Petersburg State University

\section{Research Article}

Keywords: Cryoconite, metaproteomics, glacial, anthropogenic pollution, TimsToF Pro

Posted Date: November 30th, 2021

DOl: https://doi.org/10.21203/rs.3.rs-999957/v1

License: (9) This work is licensed under a Creative Commons Attribution 4.0 International License. Read Full License 


\section{Abstract}

Anthropogenic pollution strongly affects glacial microbiological communities and promotes glacial melting. In the early stages of glacial melting formation of small cylindrical holes (cryoconite) occurs. While the microbiome of cryoconite is well described, the effect of anthropogenic pollution on cryoconite microbiological communities still has not been fully understood. Thus, we performed an unbiased functional comparison of the cryoconite communities from the highly polluted Caucasian glaciers and from less polluted glaciers in Novaya Zemlya. For this purpose, we used the shotgun metaproteomics approach which has not been used for cryoconite microbiome analysis previously. We identified 475 protein groups, a third of which were found in both glaciers. Cryoconites in both glaciers have similar microbiological communities with Cyanobacteria as dominant phyla. Nevertheless, we found a slight shift from the dominance of phototrophic Cyanobacteria in Novaya Zemlya to heterotrophic bacteria in the Caucasus. We assume that it might be caused by anthropogenic pollution, but other factors such as differences in seasonal dynamics of microbiological communities should be tested in the future.

\section{Statements And Declarations}

The authors declare that they have no known competing financial interests or personal relationships that could have appeared to influence the work reported in this paper.

Glaciers are considered to be the benchmark of airborne anthropogenic pollution [1,2]. Anthropogenic pollution may cause a darkening of the ice surface which increases solar energy absorption, and, therefore, snow and ice melting[3]. The early stage of glacial melting is the formation of cryoconitessmall cylindrical holes in the ablation zone of the glacier surface.

In addition to small rocks and inorganic particles, cryoconites also contain specific microbial communities consisting of algae, bacteria, fungi, and rotifers[4]. Cryoconite holes as a microbiological habitat were found in glaciers around the world, including polar (Arctic and Antarctic) and temperate (alpine) ice [5].Microbial growth increases the deposition of dark organic matter, causing additional snowmelt [6]. Thus, anthropogenic pollution might have an impact onthe deposition of dark organic matter through the effect on cryoconite communities.

The aim of our study is anunbiased functional comparison of the cryoconite community in two glaciers with different pollution levels. We did this bycomparing cryoconite metaproteomes in Novaya Zemlya (Mushketovaglacier with minimal anthropogenic pollution; $7905^{\prime} 46^{\prime \prime} \mathrm{N}, 10151^{\prime 2} 25,35^{\prime \prime} \mathrm{E}$ ) and in Kabardino-Balkaria (Garabashihighly polluted glacier; N $43^{\circ} 18^{\prime} 18^{\prime \prime} \mathrm{E} 42^{\circ} 27^{\prime} 49^{\prime \prime}$ ). The samples were taken from the cryoconite holes by drilling form the depth $0-20 \mathrm{~cm}$. The cryoconites consisted of skeletal fraction (up to $25 \%$ ) and fine earth (about $75 \%$ ) in both sampling sites. The pH was about 6.5-6.9, total organic carbon content was $0.05-0.25 \%$. Samples were frozen on-site and transported in frozen state to St.Petersburg. We obtained samples from five cryoconites in Kabardino-Balkaria and six in Novaya Zemlya. 
The proteins were extracted bySDS solutionand digested by standard "in-solution" methodology. The samples were analyzed by label-free shotgun proteomics with nanoLC-MS/MS with ion mobility in PASEF DDA mode on TimsToF Pro (Bruker) instrument. Proteins were identified in the Peaks X Pro softwareagainst the UniProtKBdatabase.Only protein groups with at least two unique peptides and FDR < $1 \%$ were included into further data analysis in R. A more detailed description of the proteomics analysis is given in Supplementary materials 1.

We identified 475 protein groups (fig. 1; SM2).About a third of them were found in both glaciers. Such similarity despite significant geographic distance is in good accordance with theprevious observations: cryoconites from glaciers all over the world have similar invertebrate [4] and microbial [7] fauna.

Analysis of the phylum enrichment (fig. $1 \mathrm{~b}$ ) revealed that most identified proteins were from the Cyanobacteria. Proteins from other phyla were much less represented (fig. 1 b). Contrary to this, insome Alpine glaciers the dominating component of cryoconite communitiesis heterotrophic Proteobacteria $[7,8]$.This may be due to seasonal dynamics in the Alps, with autotrophic cyanobacteria dominating after snowmelt and heterotrophic bacteria becoming dominant towards the end of summer $[9,10]$. Protein groups from the mainly heterotrophic Actinobacteria, Proteobacteria, Bacteroidetesand Acidobacteria were also abundant (fig. 1 b). Interestingly, 24 Bacteroidetes protein groups were unique for the Caucasus. Seven of them are members of SusC/RagA family TonB-linked outer membrane protein. These outer membrane proteins form transporter complexes which import degradation products of proteins or carbohydrates. Acidobacterial protein groups were also identified mostly in the Caucasus (16 versus 3 protein groups; fig. 1 b).

In the Caucasus sample we found less Cyanobacterial protein groups than in the Novaya Zemlya sample (226/250 protein groups) and more Actino- /Proteobacterial proteins ( $40 / 35$ and $13 / 16$ protein groups).

Comparison of GO annotations of protein groups specific for the Caucasus and Novaya Zemlya cryoconites also revealed shifts from autotrophic bacteriadominating in Novaya Zemlya to heterotrophic organisms in the Caucasus (fig. $1 \mathrm{c}, \mathrm{d}$ ). While in Novaya Zemlya the most enriched GO is associated with phycobilisomes, photosynthesis, protein-chromatophore linkage and thylakoid membrane; in the Caucasus the most enriched $\mathrm{GO}$ is associated with outer and cell membrane and may be regarded as transport proteins of heterotrophic bacteria.

In summary, we successfully performed metaproteomics analysis of cryoconitemicrobial communities by the shotgun proteomics with ion mobility. We compared metaproteomes of communities from cryoconites of the Caucasus (high anthropogenic pollution) and Novaya Zemlya (low anthropogenic pollution) glaciers and revealed slight shift from the dominance of phototrophic Cyanobacteria in Novaya Zemlya to heterotrophic bacteria in the Caucasus. This may be due to anthropogenic load. However, we cannot conclude this definitely due to differences in the weather conditions and temperature dynamics.Our observationsmay also be associated with seasonal shifts from autotrophic to heterotrophic communities. 


\section{Declarations}

\section{Acknowledgements}

The authors are grateful to professor Dmitry Bolshiyanov and ViacheslavPolyakov for their assistance in sampling and transportation. Proteomics analysis was performed in the Resource

Centre "Molecular and Cell Technologies" of St. Petersburg State University.

\section{Funding}

This work was supported by the Russian Foundation for Basic Research (RFBR; 19-0550107).

\section{Author Contributions}

Conceptualization, B.Z., I.B., A.L., E.A.; methodology, B.Z., A.L.; software, I.B., A.L.; validation, A.L.; formal analysis, I.B., A.L..; investigation, B.Z., I.B., A.L., R.T., E.A.; data curation, B.Z., I.B.; writing-original draft preparation, B.Z., A.L.; writing - review and editing, A.L., E.A.; visualization, I.B.; supervision, A.L., E.A.; project administration, A.L., E.A.; funding acquisition, E.A.

All authors have read and agreed to the published version of the manuscript.

\section{Competing Interest}

The authors declare no competing interests.

\section{Ethics Approval}

This article does not contain any studies with human participants or animals performed by any of the authors.

\section{Consent to Participate}

Not applicable

\section{Consent for Publication}

Not applicable

\section{Availability of data and material}

These sequence data have been submitted to the ProteomeXchange datasets under accession number PXD029568.

Raw data will be published after manuscript submission, but still available for the reviewers through the PRIDE reviewer account. 
Reviewer account details:

Username: reviewer_pxd029568@ebi.ac.uk

Password: WsU9vVDA

\section{Code Availability}

Fully reproducible code is available via https://github.com//rinaBabkina/Soil_analysis

\section{References}

[1] Ji X, Abakumov E, Antcibor I, Tomashunas V, Knoblauch C, Zubzycki S, Pfeiffer EM (2019) Influence of Anthropogenic Activities on Metals in Arctic Permafrost: A Characterization of Benchmark Soils on the Yamal and Gydan Peninsulas in Russia. Arch Environ ContamToxicol 76:540-553. https://doi.org/10.1007/s00244-019-00607-y

[2] Law KS, Stohl A (2007) Arctic air pollution: origins and impacts. Science 315:1537-1540. https://doi.org/10.1126/science.1137695

[3] Kang S, Zhang Y, Qian Y, Wang H (2020) A review of black carbon in snow and ice and its impact on the cryosphere. Earth Sci Rev 210:103346. https://doi.org/10.1016/j.earscirev.2020.103346

[4] Zawierucha K, Kolicka M, Takeuchi N, Kaczmarek $Ł$ (2015) What animals can live in cryoconite holes? A faunal review. J. Zool 295:159-169. doi:10.1111/jzo.12195

[5] Wharton RA Jr, McKay CP, Simmons GM Jr, Parker BC (1985) Cryoconite holes on glaciers. Bioscience $35: 499-503$

[6] Musilova M, Tranter M, Bamber JL, Takeuchi N, Anesio AM (2016) Experimental evidence that microbial activity lowers the albedo of glaciers. Geochem Perspect Lett 2:106-116. doi: 10.7185/geochemlet.1611

[7] Edwards A, Luis AJ Mur, Girdwood SE et al (2014) Coupled cryoconite ecosystem structure-function relationships are revealed by comparing bacterial communities in alpine and Arctic glaciers. FEMS MicrobiolEcol 89:222-237. doi:10.1111/1574-6941.12283

[8] Edwards A, Pachebat JA, Swain M et al (2013) A metagenomic snapshot of taxonomic and functional diversity in an alpine glacier cryoconite ecosystem. Enviro Res Lett 8:035003. doi:10.1088/17489326/8/3/035003

[9] Franzetti A, Navarra F, Tagliaferri I et al (2017) Potential sources of bacteria colonizing the cryoconite of an Alpine glacier. PLoS One 12:e0174786. doi:10.1371/journal.pone.0174786 
[10] Margesin R, Collins T (2019) Microbial ecology of the cryosphere (glacial and permafrost habitats): current knowledge. ApplMicrobiolBiotechnol 103:2537-2549. doi:10.1007/s00253-019-09631-3

\section{Figures}

(a)

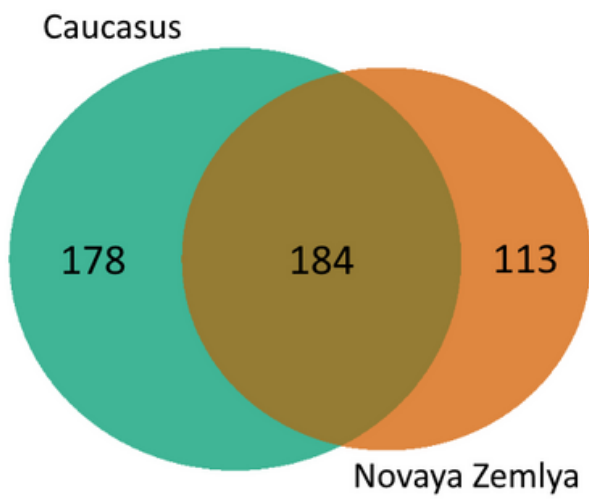

(c)

(d)

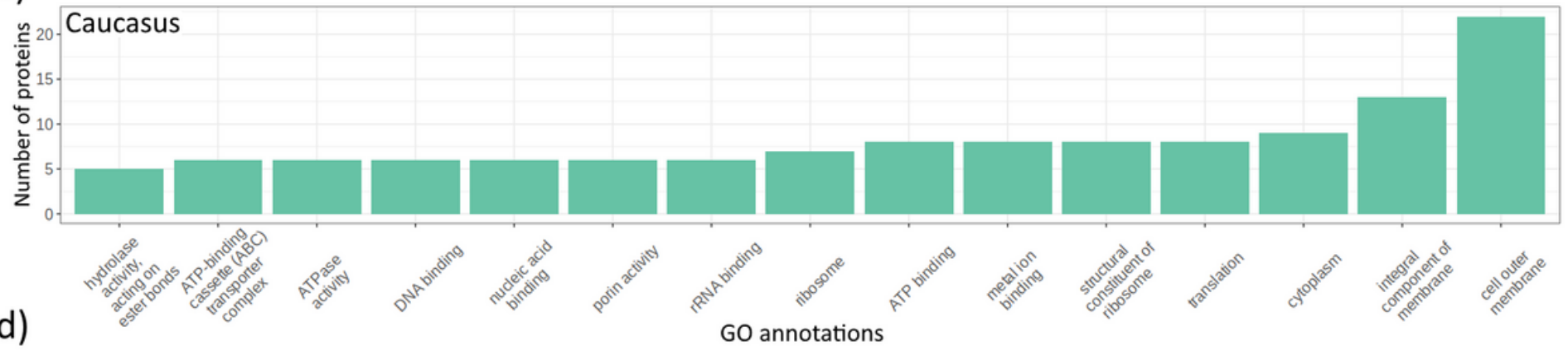

(b)

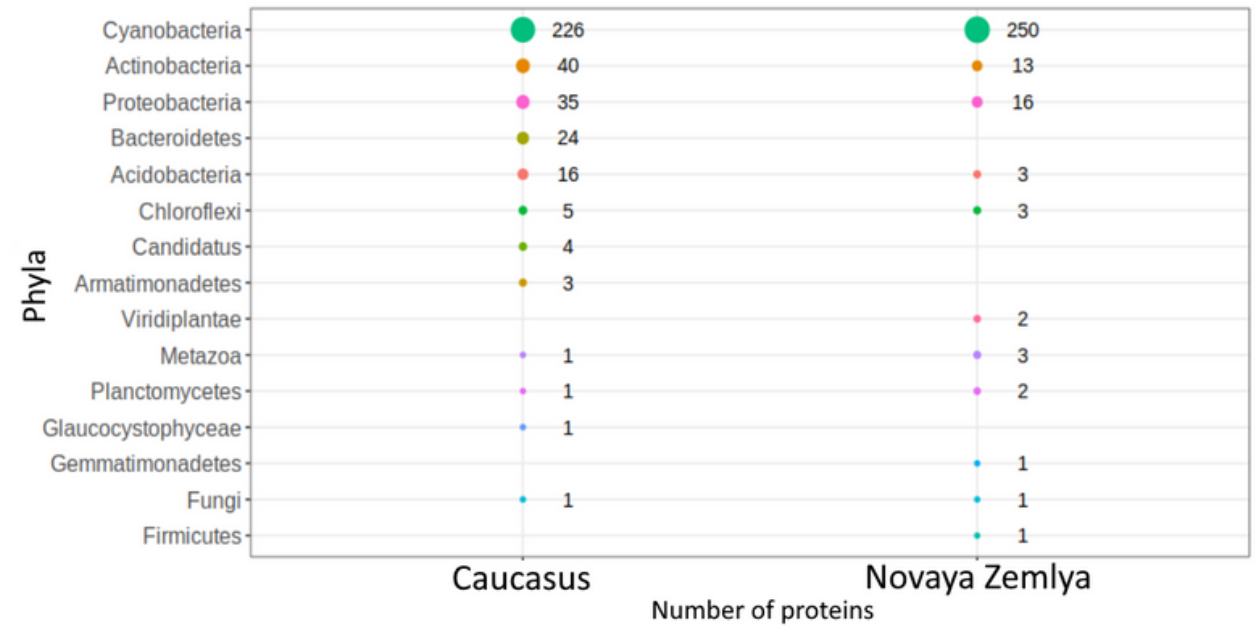

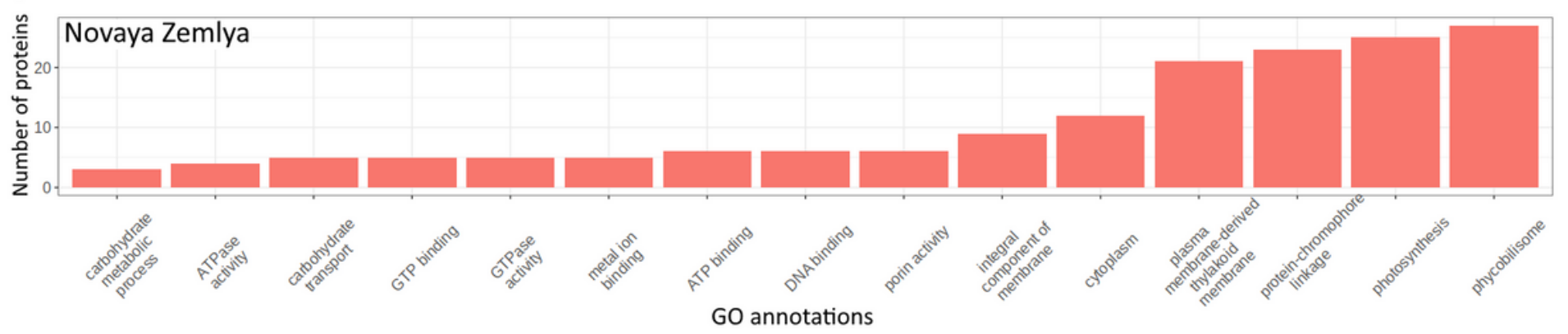

Figure 1

Metaproteomic comparison of cryoconite communities for the Caucasian and Novaya Zemlya glaciers.

(a) Venn diagram of protein groups identified in the Caucasian and Novaya Zemlya glaciers. (b)

Comparison of phyla where proteins identified in the Caucasian and Novaya Zemlya glaciers belong. (c,

d) Top-15 of gene ontology enrichment annotations of protein groups unique for cryoconites from the Caucasian(c) or Novaya Zemlya (d) glacier.

\section{Supplementary Files}


This is a list of supplementary files associated with this preprint. Click to download.

- Supplementarymaterials1.pdf

- Supplementarymaterials2.xlsx 